\title{
Bioactivities and Structure-Activity Relationships of Natural Tetrahydroanthraquinone Compounds: A Review
}

\author{
Shixiu Feng ${ }^{1 *}$ and Weiyi Wang ${ }^{2 *}$ \\ ${ }^{1}$ Key Laboratory of South Subtropical Plant Diversity, Fairy Lake Botanical Garden, Shenzhen \& Chinese Academy of \\ Sciences, Shenzhen, China, ${ }^{2}$ Key Laboratory of Marine Biogenetic Resources, Third Institute of Oceanography, Ministry of \\ Natural Resources, Xiamen, China
}

OPEN ACCESS

Edited by:

Huizi Jin,

Shanghai Jiao Tong University, China

Reviewed by: Aaditya Kashyap Bhatt, Amneal Pharmaceuticals,

United States

Sheng Xiang Qiu, South China Botanical Garden (CAS), China

*Correspondence:

Shixiu Feng

fengshixiu@scbg.ac.cn

Weiyi Wang

wywang@tio.org.cn

Specialty section: This article was submitted to Pharmacology of Anti-Cancer Drugs, a section of the journal

Frontiers in Pharmacology

Received: 17 August 2019 Accepted: 15 May 2020

Published: 27 May 2020

Citation:

Feng $S$ and Wang W (2020) Bioactivities and Structure-Activity

Relationships of Natural

Tetrahydroanthraquinone

Compounds: A Review.

Front. Pharmacol. 11:799.

doi: 10.3389/fphar.2020.00799
Tetrahydroanthraquinones are a kind of important microbial secondary metabolites with promising biological activities. Most of them were found in microorganisms, a few were derived from Chinese herbal medicine. In this review, aiming to provide basis for the further research and development of tetrahydroanthraquinone compounds, we summarized the physiological activities of natural tetrahydroanthraquinone compounds, including anticancer, anti-microbial, and antidiabetic activities. The source, structure, and action mechanisms of active tetrahydroanthraquinones are described in detail. Furthermore, this review firstly analyzed the structure-activity relationship of tetrahydroanthraquinones. Our study will serve as a valuable guideline for further research on the structural optimization, mechanism study, and development of tetrahydroanthraquinone as novel drugs. Aiming to provide references for further studies and development of tetrahydroanthraquinone compounds.

Keywords: tetrahydroanthraquinone, anti-cancer, structure-activity relationship, bioactivities, altersolanol A, bostrycin

\section{INTRODUCTION}

Anthraquinones characterized by an anthraquinone scaffold structure, are widely distributed in plant as secondary metabolites. Modern pharmacological researcher showed that anthraquinones have various potent activities, including anticancer, anti-inflammatory, anti-injury, antibacterial, anti-osteoporosis, antioxidant, etc. (Li and Jiang, 2018).

Tetrahydroanthraquinone is a class of derivatives of anthraquinone in which the unsaturated double-bonds on the benzene ring A are hydrogenated by four hydrogens (Figure 1). Most of them were found in microorganisms, while a little were derived from Chinese herbal medicine. To date, about 60 different tetrahydroanthraquinones are found, of which only nine are from plants (Wang C. et al., 2015). Because of some of tetrahydroanthraquinones showing good pharmacological activity, such as anticancer, antibacterial, anti-malarial, and anti-viral, more and more researchers 


$$
\underbrace{2}_{5}
$$

anthraquinone<smiles>CC(C)[C@H]1CC[C@H](C)C1</smiles>

tetrahydroanthraquinone
FIGURE 1 | The structure of tetrahydroanthraquinone.

are being focused on the exploration of their pharmacological activity, mechanism, and structure activity relationships.

Structurally, tetrahydroanthraquinones are generally classified into tetrahydro-9,10-anthraquinones, hydroxyphenanthrenes, tetrahydro-1,4-anthraquinones, and bi-tetrahydroanthraquinone, and according to their sources, tetrahydroanthraquinones can be divided into the ones from microorganisms and the ones from plants. In this paper, we focus on the pharmacological activities and related structure-activity relationships of active tetrahydroanthraquinones, aiming to provide references for further studies and development of tetrahydroanthraquinone compounds.

\section{STRUCTURE AND CLASSIFICATION}

\section{Tetrahydroanthraquinones From Microorganisms}

\section{Tetrahydro-9,10-Anthraquinones}

The tetrahydroanthraquinone ring is the fundamental parent nucleus of tetrahydroanthraquinones (Figure 1). Hydroxyls could locate in the $\mathrm{C}-1$ to $\mathrm{C}-8$ positions. In general, a compound with single tetrahydroanthraquinone nucleus is called a tetrahydro-9,10-anthraquinone. There are nineteen tetrahydro-9,10-anthraquinones that were isolated from endophytes and marine strains (Table $\mathbf{1}$ and Figure 2). Besides, nine kinds of tetrahydro-9,10-anthraquinones extracted from the root of Prismatomeris connata, and they are named as prisconnatanones A-I (Table 1 and Figure 2). Most tetrahydro-9,10-anthraquinones isolated from microorganisms have a structure with 5-OH and 7-OCH3, and substituent groups

TABLE 1 | The source and activities of tetrahydro-9,10-anthraquinones compounds.

\begin{tabular}{|c|c|c|c|c|}
\hline No & Name & Source & Activities & Reference \\
\hline 1 & Altersolanol A & Alternaria solani & $\begin{array}{l}\text { Antitumor activity; } \\
\text { Antibacterial activity }\end{array}$ & (Stoessl, 1969a; Mishra et al., 2015; Zhang N. et al., 2016) \\
\hline 2 & Altersolanol B & A. solani & Antibacterial activity & (Stoessl, 1969a; Yagi et al., 1993) \\
\hline 3 & Altersolanol C & Dactylaria lutea & Antibacterial activity & (Becker et al., 1978; Yagi et al., 1993) \\
\hline 4 & Altersolanol D & A. solani & - & (Yagi et al., 1993) \\
\hline 5 & Altersolanol E & A. solani & Antibacterial activity & (Becker et al., 1978; Yagi et al., 1993) \\
\hline 6 & Altersolanol F & A. solani & Antitumor activity & (Yagi et al., 1993; Bin et al., 2016) \\
\hline 7 & Altersolanol P & Staphylococcus aureus & - & (Becker et al., 1978) \\
\hline 8 & Altersolanol O & Alternaria sp. XZSBG-1 & - & (Chen et al., 2014) \\
\hline 9 & Auxarthrol C & Stemphylium sp. 33231. & - & (Zhou et al., 2014) \\
\hline 10 & Dihydroaltersolanol B & Stemphylium globuliferum & - & (Liu et al., 2015) \\
\hline 11 & Dihydroaltersolanol C & Stemphylium globuliferum & - & (Liu et al., 2015) \\
\hline 12 & 4-dehydroxyaltersolanol A & Nigrospora oryzae & $\begin{array}{l}\text { Antitumor activity; } \\
\text { Hypoglycemic }\end{array}$ & (Uzor et al., 2015) \\
\hline 13 & 2-O-aectylaltersolanol B & Stemphylium sp. 33231. & - & (Zhou et al., 2014) \\
\hline 14 & Trichodermaquinone & $\begin{array}{l}\text { Trichoderma aureoviride PSU- } \\
\text { F95 }\end{array}$ & Antibacterial activity & (Khamthong et al., 2012) \\
\hline 15 & Coniothranthraquinone 1 & T. aureoviride PSU-F95 & Antibacterial activity & (Khamthong et al., 2012; Ng et al., 2015) \\
\hline 16 & Phomopsanthraquinone & Phomopsis sp. PSU-MA214. & - & (Klaiklay et al., 2012) \\
\hline 17 & SZ-685C & fungus No. 1403 & Antitumor activity & $\begin{array}{l}\text { (Xie et al., 2010; Zhu et al., 2012; Chen et al., 2013; Wang } \\
\text { et al., 2013; Wang X. et al., 2015) }\end{array}$ \\
\hline 18 & Prisconnatanone A & Prismatomeris connata & Antitumor activity & (Feng et al., 2011; Feng et al., 2016; Feng et al., 2018) \\
\hline 19 & Prisconnatanone B & P. connata & - & (Feng et al., 2011) \\
\hline 20 & Prisconnatanone C & P. connata & - & (Wang C. et al., 2015) \\
\hline 21 & Prisconnatanone D & P. connata & - & (Wang C. et al., 2015) \\
\hline 22 & Prisconnatanone E & P. connata & - & (Wang C. et al., 2015) \\
\hline 23 & Prisconnatanone F & P. connata & - & (Wang C. et al., 2015) \\
\hline 24 & Prisconnatanone G & P. connata & - & (Wang C. et al., 2015) \\
\hline 25 & Prisconnatanone $\mathrm{H}$ & P. connata & - & (Wang C. et al., 2015) \\
\hline 26 & Prisconnatanone I & P. connata & Antitumor activity & (Wang C. et al., 2015) \\
\hline 27 & $\begin{array}{l}\text { 1,2,4,5-tetrahydroxy-7-methoxy-2-methyl- } \\
\text { 1,2,3,4-tetrahydroanthracene-9,10-dione }\end{array}$ & Alternaria sp. & - & (Phunlap et al., 2013) \\
\hline 28 & $( \pm)$-4-deoxyaustrocortilutein (4-DACL) & Derivative & - & (Genov et al., 2016) \\
\hline
\end{tabular}




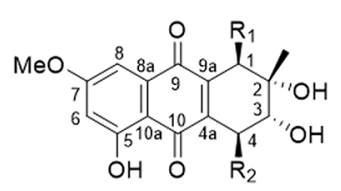

$1 \mathrm{R}_{1}=\mathrm{OH}, \mathrm{R}_{2}=\mathrm{OH}$

$2 \mathrm{R}_{1}=\mathrm{H}, \quad \mathrm{R}_{2}=\mathrm{H}$

$3 \mathrm{R}_{1}=\mathrm{OH}, \mathrm{R}_{2}=\mathrm{H}$<smiles>C[C@]1(O)CCC2=C(C(=O)c3c(O)cccc3C2=O)[C@@H]1O</smiles>

7<smiles>[R1]C1[C@](C)(O)[C@@H](O)C[C@H]2C(=O)c3c(O)cc(OC)cc3C(=O)[C@@]12C</smiles>

$10 \mathrm{R}_{1}=\mathrm{H}, \mathrm{R}_{2}=\mathrm{OH}$

$11 \mathrm{R}_{1}=\mathrm{OH}, \quad \mathrm{R}_{2}=\mathrm{H}$<smiles>[R]c1cc(O)c2c(c1)C(=O)C1=C(C[C@H](O)[C@H](O)C1)C2=O</smiles>

$$
14 \mathrm{R}_{1}=\mathrm{CH}_{2} \mathrm{OH}
$$$$
15 \mathrm{R}_{1}=\mathrm{CH}_{3}
$$<smiles>COc1cc2c(c(OC)c1OC)C(=O)C1=C(C[C@H](C)[C@H](O)C1)C2=O</smiles>

21<smiles>COc1cc2c(c(O)c1OC)C(=O)C1=C(C2=O)[C@@H](O)[C@H](O)[C@@H](C)C1</smiles>

26<smiles>[R6]c1cc(O)c2c(c1)C(=O)C1=C(C2=O)C(O)C(C)C(C)(O)C1[R1]</smiles>

$4 \mathrm{R}_{1}=\mathrm{OH}, \mathrm{R}_{2}=M e, \mathrm{R}_{3}=\mathrm{H}$

$5 \mathrm{R}_{1}=\mathrm{H}, \quad \mathrm{R}_{2}=\mathrm{H}, \quad \mathrm{R}_{3}=\mathrm{Me}$<smiles>COc1cc(O)c2c(c1)C(=O)C1(O)C(O)C2C(O)(O)C(C)(O)C1O</smiles>

8<smiles>COc1cc(O)c2c(c1)C(=O)C1=C(C2)[C@H](O)[C@H](O)[C@@](C)(O)C1</smiles>

12<smiles>CCc1c(OC)cc2c(c1O)C(=O)C1=C(C[C@](C)(O)[C@H](O)C1)C2=O</smiles>

16<smiles>[R]c1c([R])c(OC)c2c(c1[R1])C(=O)C1=C(C[C@H](O)[C@H](C)C1)C2=O</smiles>

$18 \mathrm{R}_{1}=\mathrm{H}, \quad \mathrm{R}_{2}=\mathrm{OMe}, \mathrm{R}_{3}=\mathrm{H}$

$19 \mathrm{R}_{1}=\mathrm{Me}, \mathrm{R}_{2}=\mathrm{H}, \quad \mathrm{R}_{3}=\mathrm{H}$

$20 \mathrm{R}_{1}=\mathrm{Me}, \mathrm{R}_{2}=\mathrm{OMe}, \mathrm{R}_{3}=\mathrm{H}$

$22 R_{1}=M e, R_{2}=O M e, R_{3}=O M e$

$23 \mathrm{R}_{1}=\mathrm{H}, \quad \mathrm{R}_{2}=\mathrm{OMe}, \mathrm{R}_{3}=\mathrm{OMe}$

$24 \mathrm{R}_{1}=\mathrm{Me}, \mathrm{R}_{2}=\mathrm{OMe}, \mathrm{R}_{3}=\mathrm{OH}$

$25 \mathrm{R}_{1}=\mathrm{H}, \quad \mathrm{R}_{2}=\mathrm{OMe}, \mathrm{R}_{3}=\mathrm{OH}$<smiles>COc1cc(O)cc2c1C(=O)C1=C(C2=O)[C@H](O)[C@@H](O)[C@@](C)(O)[C@H]1O</smiles>

6<smiles>COc1cc(O)c2c(c1)C(=O)[C@@]13O[C@]1(C2=O)[C@H](O)[C@@](C)(O)[C@H](O)[C@H]3O</smiles>

9<smiles>COc1cc(O)c2c(c1)C(=O)C1=C(C[C@H](OC(C)=O)[C@](C)(O)C1)C2=O</smiles>

13<smiles>COc1cc(O)c2c(c1O)C(=O)C1=C(C2=O)[C@@H](O)[C@H](O)[C@@](C)(O)C1</smiles>

17<smiles>[R]C1[C@H](O)C2=C(C(=O)c3c(O)cc(OC)cc3C2=O)[C@H](O)[C@@]1(C)O</smiles>

27<smiles>COc1cc(O)c2c(c1)C(=O)[C@@H]1CC(C)(O)CC[C@H]1C2=O</smiles>

28

FIGURE 2 | The structure of tetrahydro-9,10-anthraquinones compounds (1-28).

at A ring can be variable. However, tetrahydro-9,10anthraquinones extracted from $P$. connata have a basic structure with $2-\mathrm{OH}(\mathrm{R})$ and $3-\mathrm{CH} 3(\mathrm{R})$, and their $\mathrm{C}$ ring mostly substituted with hydroxyl and methoxy groups.

\section{Hydroxyphenanthrenes}

Hydroxyphenanthrene is a class of compounds in which the C-9 or C-10 position is hydrogenated to a hydroxyl group compared to a tetrahydroanthraquinone, and generally named as 10hydroxy-1,3,4,4a,9a,10-hexahydrohydroanthracene-9(2H)-one. There are ten hydroxyphenanthrenes that has been isolated and identified. Their detailed source and structure information were displayed in Table 2 and Figure 3.

\section{Tetrahydro-5,8-Anthraquinones}

Tetrahydro-5,8-anthraquinones is a class of compounds in which 
TABLE 2 | The source and activities of hydroxyphenanthrene compounds.

\begin{tabular}{|c|c|c|c|c|}
\hline No & Name & Source & Activities & Reference \\
\hline 29 & Altersolanol J & NRRL 29097 & - & (Höller et al., 2002) \\
\hline 30 & Altersolanol $\mathrm{K}$ & Stemphylium globuliferum & - & (Debbab et al., 2009) \\
\hline 31 & Altersolanol L & S. globuliferum & - & (Debbab et al., 2009) \\
\hline 32 & Tetrahydroaltersolanol B & Phomopsis sp. PSU-MA214 & - & (Klaiklay et al., 2012) \\
\hline 33 & Tetrahydroaltersolanol C & Phomopsis sp. PSU-MA214 & Antiviral activity & (Klaiklay et al., 2012; Zhang S.L. et al., 2016) \\
\hline 34 & Ampelanol & Ampelomyces sp. & - & (Aly et al., 2008) \\
\hline 35 & Xylanthraquinone & Xylaria sp. 2508 & - & (Huang et al., 2014) \\
\hline 36 & 2-O-aectylaltersolanol L & Stemphylium sp. 33231 & - & (Zhou et al., 2014) \\
\hline 37 & Altersolanol Q & Stemphylium globuliferum & - & (Moussa et al., 2016) \\
\hline 38 & 10-methylaltersolanol Q & S. globuliferum & - & (Moussa et al., 2016) \\
\hline
\end{tabular}

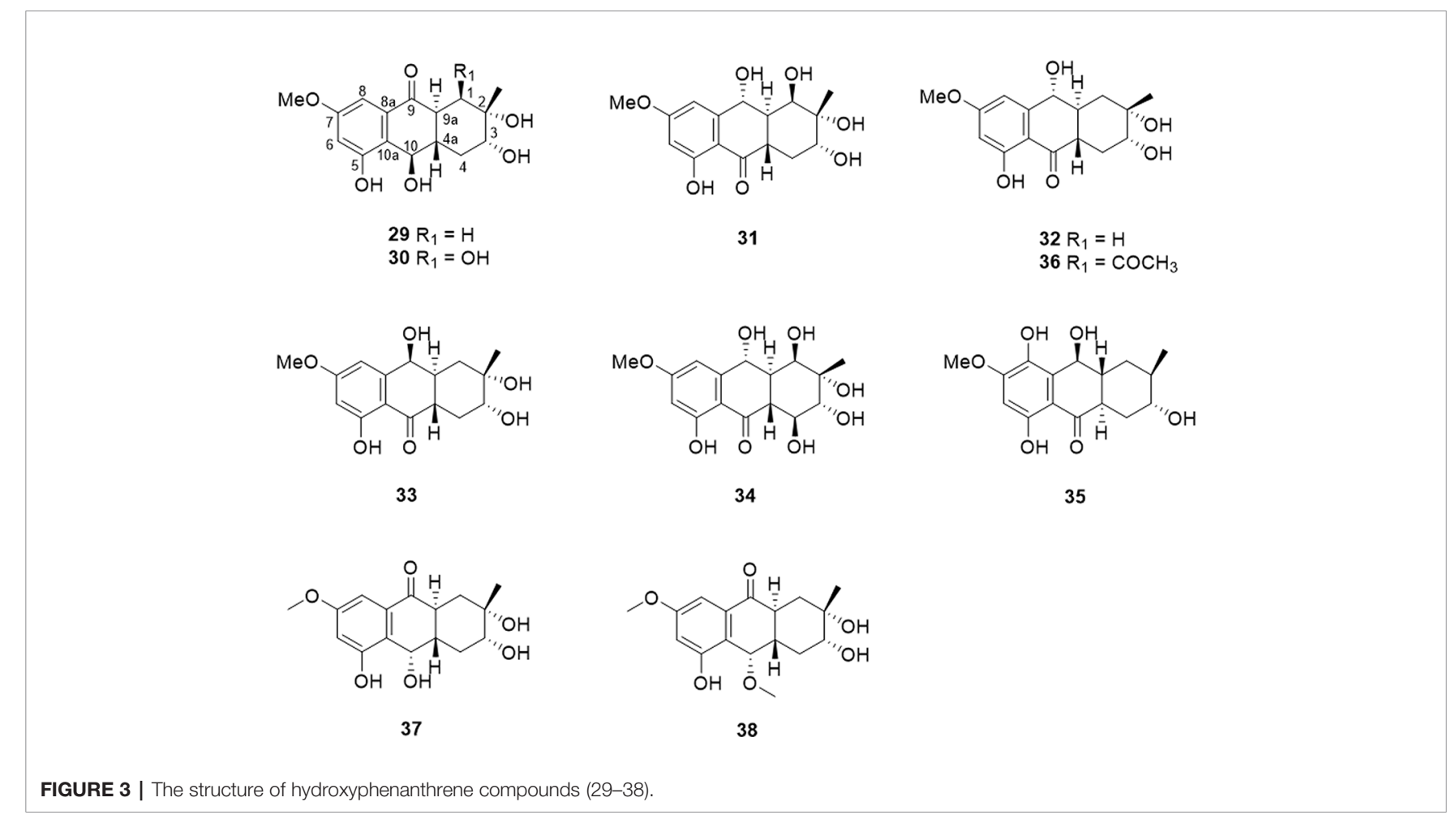

the $\mathrm{C} 5$ and $\mathrm{C} 8$ positions of a tetrahydroanthraquinone are oxidized to a ketone group. They are rare in natural products due to their instability. In nature, most of anthraquinones and tetrahydroanthraquinones exist in the form of $\mathrm{C} 9$ and $\mathrm{C} 10$ ketone groups. Although rare, five Tetrahydro-5,8-anthraquinones have been isolated and identified as (1S,3R)-austrocortirubin (6methoxy-1 $\beta, 3 \beta, 9,10$-tetrahydroxy-3 $\alpha$-methylanthracene- 9,10 dione), (1S,3S)- austrocortirubin (6-methoxy-1 $1,9,10$-trihydroxy$3 \alpha, 3 \beta$-dimethylanthracene-9,10-dione), 1-deoxyaustrocortirubin (7-methoxy-2 $\beta, 9,10$-trihydroxy-2 $\alpha$-methylanthracene-9,10-dione), deoxybostrycin (7-methoxy-2 $\beta, 3 \beta, 9,10$-tetrahydroxy- $2 \alpha$ methylanthracene-9,10-dione), and bostrycin (7-methoxy$1 \alpha, 2 \beta, 3 \beta, 9,10$-pentahydroxy-3 $\alpha$-methylanthracene-9,10-dione). The detailed source and structure information was displayed in Table 3 and Figure 4.

\section{Bi-Tetrahydroanthraquinones}

Bi-tetrahydroanthraquinones were formed by two tetrahydroanthraquinones or a tetrahydroanthraquinone and an anthraquinone through dehydration condensation to establish dimeric alterporriols. Seventeen bi-tetrahydroanthraquinones have been reported (Table 4 and Figure 5), among which based on the type of the monomeric units, biaryl linkage, presence of axial chirality, they could be further classified as anthraquinone connected to tetrahydroanthraquinone unit via C-5-C-5' biaryl linkage $(44,45,51,55$, and 56), and C-7-C-5' biaryl linkage (48, 49, 59 , and 60). As to the bi-tetrahydroanthraquinone units, compounds $46,47,50,57$, and 58 coupled by C-5-C-5' biaryl linkage, compounds 53 and 54 presented a C-7-C-5' biaryl linkage, only compound 52 featured a C-4-C-4' cyclohexene connection. Moreover, compounds 50,52, 53, and 54 demonstrated as axial 
TABLE 3 | The source and activities of tetrahydro-5,8-anthraquinones compounds.

\begin{tabular}{|c|c|c|c|c|}
\hline No & Name & Source & Activities & Reference \\
\hline 39 & $(1 S, 3 R)$-austrocortirubin & Dermocybe splendida & - & (Elsworth et al., 1999) \\
\hline 40 & $(1 S, 3 S)$-austrocortirubin & Cortinarius sp & Antitumor activity & (Choomuenwai et al., 2012; Wang Y. et al., 2015) \\
\hline 41 & 1-deoxyaustrocortirubin & Cortinarius sp & - & (Choomuenwai et al., 2012) \\
\hline 42 & Deoxybostrycin & Xylaria sp. 2508 & $\begin{array}{l}\text { Antitumor activity; Antibacterial activity; Antimalarial } \\
\text { activity }\end{array}$ & $\begin{array}{l}\text { (Xuekui et al., 2011; Cong et al., 2013; Huang et al., } \\
\text { 2014) }\end{array}$ \\
\hline 43 & Bostrycin & Xylaria sp. 2508 & Antitumor activity; Antibacterial activity & (Dongni et al., 2013; Huang et al., 2014) \\
\hline
\end{tabular}<smiles>COc1cc(=O)c2c(O)c3c(=O)cc(OC)c(=O)c3c(O)c2c1=O</smiles>

chirality monomers, compounds 44 and 45 , compounds 46 and 47, compounds 48 and 49 were atropodia steremoers.

\section{PHARMACOLOGICAL EFFECTS}

\section{Anti-Tumor Activity Anti-Tumor Activity of Tetrahydro-9,10- Anthraquinones}

Some natural anthraquinones have been proven to have anti-tumor effects, such as rhein and emodin (Li and Jiang, 2018; Han et al., 2018). Tetrahydroanthraquinones, a class of anthraquinones, can also exhibit anti-cancer activity such as inhibiting cell proliferation, invasion, metastasis, and angiogenesis by inducing cell apoptosis, arresting cell cycle or suppressing the relevant enzymes. Altersolanol A, one of the most researched tetrahydroanthraquinone, exhibits antitumor activities against broad spectrum cancers (bladder, colon, gastric cancers, etc.) (Zhang N. et al., 2016). It can inhibit the proliferation and migration of both adherent cells K562 and nonadherent cells A549, whereas leave non-cancer cells (PBMCs cells) unaffected (Teiten et al., 2013). The anti-tumor activity of Altersolanol A is correlated with its pro-apoptotic and antiinvasive effect due to the inhibition of NF- $\mathrm{KB}$ transcription (Teiten et al., 2013). Another study also showed Altersolanol A exerted anti-cancer activity by inhibiting angiogenesis at low concentration in vitro and in vivo, and suppress the proliferation, tube formation, and migration of endothelial cells (Phunlap et al.,

TABLE 4 | The source and activities of Bi-tetrahydroanthraquinones compounds.

\begin{tabular}{|c|c|c|c|c|}
\hline No & Name & Source & Activities & Reference \\
\hline 44 & Alterporriol A & Stemphylium sp. 33231 & - & (Zhou et al., 2014) \\
\hline 45 & Alterporriol B & Stemphylium sp. 33231 & - & (Zhou et al., 2014) \\
\hline 46 & Alterporriol D & Pleospora herbarum & - & (Kanamaru et al., 2012) \\
\hline 47 & Alterporriol E & P. herbarum & - & (Kanamaru et al., 2012) \\
\hline 48 & Alterporriol G & Stemphylium globuliferum & Antibacterial activity & (Aly et al., 2008; Debbab et al., 2009) \\
\hline 49 & Alterporriol $\mathrm{H}$ & S. globuliferum & - & (Debbab et al., 2009) \\
\hline 50 & Alterporriol F & Pleospora herbarum & - & (Kanamaru et al., 2012) \\
\hline 51 & Alterporriol N & Alternaria sp. XZSBG-1 & - & (Chen et al., 2014) \\
\hline 52 & Alterporriol S & Alternaria sp. XZSBG-1 & - & (Chen et al., 2014) \\
\hline 53 & Alterporriol $\mathrm{T}$ & Stemphylium sp. 33231 & - & (Zhou et al., 2014) \\
\hline 54 & Alterporriol U & Stemphylium sp. 33231 & - & (Zhou et al., 2014) \\
\hline 55 & Alterporriol V & Alternaria sp. XZSBG-1 & - & (Chen et al., 2014) \\
\hline 56 & Alterporriol W & Stemphylium sp. 33231 & - & (Zhou et al., 2014) \\
\hline 57 & Aectylalterporriol D & S. globuliferum & - & (Liu et al., 2015) \\
\hline 58 & Aectylalterporriol E & S. globuliferum & - & (Liu et al., 2015) \\
\hline 59 & Alterporriol X & S. globuliferum & - & (Moussa et al., 2016) \\
\hline 60 & Alterporriol L & Alternaria sp. ZJ9-6B & Antitumor activity & (Huang et al., 2012) \\
\hline
\end{tabular}




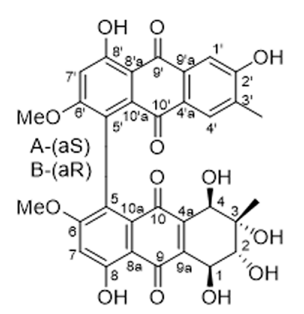

$44 / 45$<smiles>COc1cc(O)c2c(c1-c1c(OC)cc(O)c3c1C(=O)C1=C(C3=O)[C@H](O)[C@H](O)C[C@H]1O)C(=O)C1=C(C2=O)[C@@H](O)[C@@](C)(O)[C@](C)(O)[C@H]1O</smiles>

50<smiles>COc1cc(O)c2c(c1-c1c(OC)cc(O)c3c1C(=O)C1=C(C[C@H](O)[C@](C)(O)[C@H]1O)C3=O)C(=O)C1=C(C[C@](C)(O)[C@H](O)C1)C2=O</smiles>

53<smiles>COc1cc(O)c2c(c1)C(=O)c1cc(C)c(O)c(-c3c(OC)cc(O)c4c3C(=O)C3=C(C4=O)[C@@H](O)[C@](C)(O)[C@H](O)C3)c1C2=O</smiles>

56

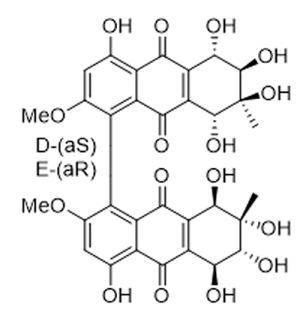

$46 / 47$

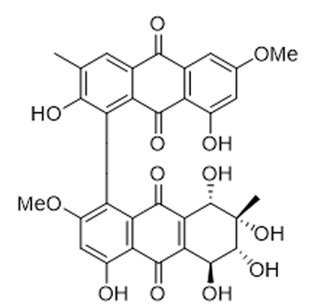

51

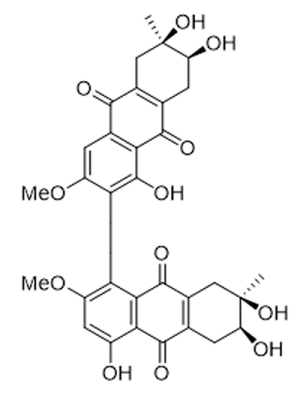

54

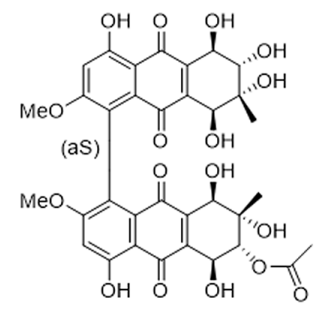

57

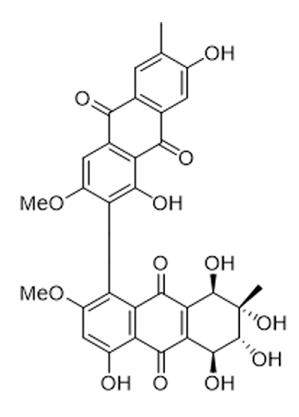

$48 / 49$

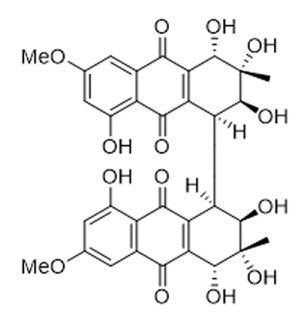

52
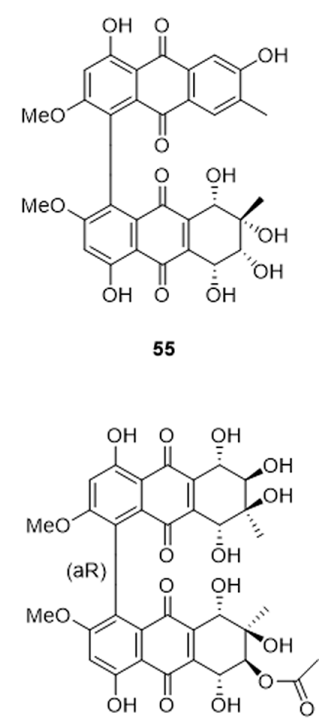

58

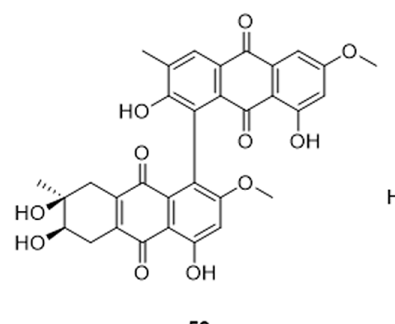

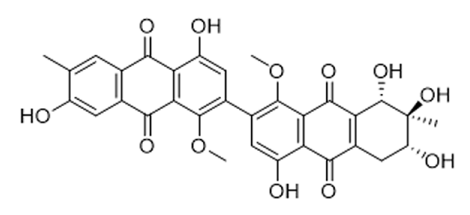

59

60

FIGURE 5 | The name of bi-tetrahydroanthraquinones compounds (44-60). 
2013). Altersolanol F impaired the viability of colorectal cancer HCT-116 cells and cervical cancer Hela cells (Bin et al., 2016). 4Dehydroxyaltersolanol A showed cytotoxicity against L5178Y mouse lymphoma cells with $\mathrm{IC}_{50}$ value of $9.4 \mu \mathrm{M}$ (Uzor et al., 2015). Altersolanol $\mathrm{N}$ and alterporriol $\mathrm{G}$ were also cytotoxic towards the murine cancer cell line L5178Y (Aly et al., 2008). SZ-685C, isolated from Halorosellinia sp. (No. 1403), exhibits broad spectrum of antitumor activity. A study showed it inhibits the growth of human glioma, hepatoma, prostate cancer, and breast cancer cells with $\mathrm{IC}_{50}$ values ranging from 3.0 to $9.6 \mu \mathrm{M}$ (Xie et al., 2010). In vivo experiment indicated that SZ-685C could suppress the tumor growth in nude mice by inducing apoptosis through the Akt/FOXO pathway (Xie et al., 2010). In addition, SZ-685C was reported to induce apoptosis in primary human nonfunctioning pituitary adenoma cells and adriamycin-resistant human breast cancer cells by inhibition of the Akt Pathway (Zhu et al., 2012; Wang X. et al., 2015). Moreover, recent studies found that it may play antitumor function through regulating the expression of micro RNAs. Chen et al. (2013) reported that SZ-685C inhibited the proliferation of rat pituitary adenoma MMQ cells and induced cell apoptosis through downregulating the expression of miR-200c. Dujuan Wang et al. (2013) suggested that SZ-685C abrogated the radio resistance of human nasopharyngeal carcinoma CNE2 cells through the miR-205 -PTEN-Akt pathway. ( \pm )-4-deoxyaustrocortilutein treatment induced mitochondrial ROS, reduced NF- $\kappa B$ signaling activity and increased up-regulation of the cell cycle inhibitors cyclindependent kinase inhibitor p21 (p21WAF1/Cip1) and the tumor suppressor protein p53 in a dose-dependent manner (Genov et al., 2016).

Prisconnatanones A and I were isolated from Prismatomeris connata, showed strong anticancer activity. Prisconnatanones A (HG30) inhibits the proliferation of HEp-2, A549, and H1299 cells, inducing apoptosis through caspase-dependent apoptosis pathways and disturbing the balance between Bcl-2 and IAP families, in addition, its cytotoxicity was associated with the cell cycle arrest at G2/M phase (Feng et al., 2016; Feng et al., 2018). Prisconnatanone I showed the highest activity, with $\mathrm{IC}_{50}$ values ranging from $2.7 \mu \mathrm{M}$ to $3.9 \mu \mathrm{M}$ in the suppression of lung tumor cell growth (H1229, HTB179, A549, and H520), while compounds Prisconnatanone $\mathrm{C}-\mathrm{H}$ had relatively low values ( $\mathrm{IC}_{50}, 2.7 \mu \mathrm{M}$ to $3.9 \mu \mathrm{M}$ ) (Wang C. et al., 2015). In conclusion, these data suggest that some natural tetrahydroanthraquinones are bioactive, and hydroxylation at C-1 significantly increases the cytotoxicity of these compounds against lung tumor cells growth.

\section{Anti-Tumor Activity of Tetrahydro-5, 8- Anthraquinones}

(1S,3S)-austrocortirubin, a tetrahydro-5, 8-anthraquinones, has a $\mathrm{GI}_{50}$ of $3 \mu \mathrm{M}$ against colon cancer HCT116 cells and induces apoptosis via inducing DNA damage. It causes significant DNA damage during G0/G1, S, and G2 cell cycle phases. Cells are stopped at the G2/M phase checkpoint, and do not reach mitosis due to large amounts of DNA damage (Wang Y. et al., 2015). Deoxybostrycin exerted cytotoxicity against A549, Hep-2, Hep G2, KB, MCF-7, and MCF-7/Adr cells with $\mathrm{IC}_{50}$ values of 2.44, $3.15,4.41,3.15,4.76$, and $5.46 \mu \mathrm{g} / \mathrm{ml}$, respectively. Bostrycin also inhibited the growth of these same cancer cell lines with $\mathrm{IC}_{50}$ values of $2.64,5.39,5.90,4.19,6.13$, and $6.68 \mu \mathrm{g} / \mathrm{ml}$, respectively (Xuekui et al., 2011). For bostrycin, previous study reported it inhibited cell proliferation via upregulation of miRNA-638 and miRNA-923 and downregulation of the PI3K/Akt pathway (Wei-Sheng et al., 2011). Besides, it could induce apoptosis and cell cycle arrest in A549 cells (Wei-Sheng et al., 2011). Further study uncovered that bostrycin inhibits the proliferation of breast cancer cells through changing the structure of PTP1B (protein tyrosine phosphatase $1 \mathrm{~B}$ ) and inhibiting its activity (Dongni et al., 2013).

To further explore the structure-activity relationship of bostrycin, Hong Chen et al. (2012) synthesized 18 bostrycin derivatives through structural modification at positions $2,3,6$, and 7. And found that dioxylcarbonyl groups at C-2 and C-3 positions, tertiary amino groups at C- 6 position and alkylthio groups at C- 6 and C-7 positions of the bostrycin could enhance cytotoxicity of bostrycin derivatives.

\section{Anti-Tumor Activity of Bi-Tetrahydroanthraquinones}

Alterporriol L could effectively inhibit the proliferation and growth of breast cancer cell line MCF-7 ( $\left.\mathrm{IC}_{50}, 13.11 \mu \mathrm{M}\right)$ and MDA-MB-435 cells $\left(\mathrm{IC}_{50}, 20.04 \mu \mathrm{M}\right)$, and there was a dosedependent manner of cell death. Moreover, alterporriol L could induce cancer cell apoptosis and necrosis through triggering the generation of oxidative stress (Huang et al., 2012).

It is interesting that we have not found any report of hydroxyphenanthrenes with anti-tumor activity. This may suggest that the tetrahydroanthraquinone skeleton with carbonyl groups at C-9 and C-10 positions is important for the anti-tumor activity of tetrahydroanthraquinones.

\section{Antimicrobial Activity}

Many tetrahydroanthraquinones exhibit good antimicrobial activities. Altersolanols A-C and E inhibited the growth of all Gram-positive bacteria and Pseudomonas aeruginosa IF0 3080 with minimum inhibitory concentration (MIC) value ranging from 12.5 to $25 \mu \mathrm{g} / \mathrm{ml}$. However, Altersolanol D and F, lack of hydroxy group at C-5 compared to Altersolanols A-C and E, even at concentration as high as $100 \mu \mathrm{g} / \mathrm{ml}$, have not inhibited bacteria growth. This indicated that the hydroxy group at C-5 position was necessary to the antibacterial activities of tetrahydroanthraquinones (Yagi et al., 1993). Coniothranthraquinone 1 showed antibacterial activity against Staphylococcus aureus ATCC 25923 (SA) and Staphylococcus aureus SK1 (MRSA), with MIC values of 16 and 8 $\mu \mathrm{g} / \mathrm{ml}$, respectively (Khamthong et al., 2012; Ng et al., 2015). While trichodermaquinone showed antibacterial activity against MRSA, with a MIC value of $200 \mu \mathrm{g} / \mathrm{ml}$, had no inhibition on SA (Khamthong et al., 2012). This study suggested that the hydroxyl group at C-5 position and the methyl group at C-7 position are important to the antibacterial activity of a tetrahydroanthraquinone. Deoxybostrycin and Bostrycin showed strong antimicrobial activities against Staphylococcus aureus, Escherichia coli, Pseudomonas aeruginosa, Sarcina ventriculi, Bacillus subtilis with an IC50 of $3.13 \mu \mathrm{g} / \mathrm{ml}$, and inhibited Candida albicans with an IC50 of $12.5 \mu \mathrm{g} / \mathrm{ml}$. Besides, Deoxybostrycin showed good anti- 
mycobacterial activity, it exhibited a better inhibitory effect on clinical multidrug-resistant M. tuberculosis (K2903531 and 0907961) than the first line anti-tuberculosis drug (Nigrosporin) (Yagi et al., 1993). Alterporriol G showed antibacterial activity only against Streptomyces pneumonia (Aly et al., 2008).

\section{Antiviral Activity}

Tetrahydroaltersolanol C exhibited a significant anti-PRRSV (Porcine reproductive and respiratory syndrome virus) activity with a $\mathrm{EC}_{50}$ value of $12.11 \mu \mathrm{M}$, it inhibited the internalization and replication of PRRSV, but did not directly inactivate the virus or block its adsorption to cell surface (Zhang S.L. et al., 2016).

\section{Antidiabetic Activity}

4-des-hydroxyl altersolanol A significantly reduced the level of blood sugar in alloxan-induced diabetic mice (Uzor et al., 2017).

\section{CONCLUSIONS AND PERSPECTIVES}

Anthraquinone compounds and their natural derivatives, especially tetrahydroanthraquinones, showed a considerably wide range of pharmacological effects, and 60 tetrahydroanthraquinones have been found since altersolanol A was originally reported in 1967 (Stoessl, 1969b). Some of them exhibited considerable cytotoxicity, antimicrobial, antiviral activity, and hypoglycemic activities. In this review, anti-tumor, anti-microbial, antiviral activity, and antidiabetic activities of tetrahydroanthraquinones are summarized in detail, and 17 active ones are involved. We try to sum up the structure and activity relationship of tetrahydroanthraquinones from previous literatures.

Anthraquinones exhibited potent antitumor effect, while they also with DNA toxicity, can be inserted into the helical structure of DNA in the form of a flat structure, affecting the transcription and DNA replication (Adhikari and Mahar, 2016). Hence, anthraquinones showed stronger toxicity than pharmacological effect. Tetrahydroanthraquinones, especially tetrahydro-9,10anthraquinones, avoided DNA toxicity caused by anthraquinone planar structure. Tetrahydroanthraquinone forms a dimensional construct of cyclohexene after hydrogenation, and forms two or more chiral centers by substitution with $\mathrm{OH}$ or $\mathrm{CH}_{3}$. This increased the potential druggability and formed multiple targeting centers, providing more possibilities for chemical modification and structure transformation. There are few reports in the available literature that the antitumor effect of tetrahydroanthraquinone is related to DNA toxicity, except for (1S,3S)-austrocortirubin (Wang Y. et al., 2015). More studies suggested that the antitumor effect of tetrahydroanthraquinone is through targeting signaling pathways, including NF-אB, PI3K/Akt pathway (Xie et al., 2010; Zhu et al., 2012; Genov et al., 2016). Suggesting that the antitumor mechanisms of tetrahydroanthraquinones are different from that of anthraquinone. Tetrahydroanthraquinones deserve more attention and more research.

For anti-cancer activity, it seems that the p-quinone moiety of tetrahydroanthraquinone is fundamental, as reduction of one of the carbonyl groups of the quinone moiety nullified the cytotoxicity of the tetrahydroanthraquinone derivatives (Zhang N. et al., 2016). Adding short side chains to the benzoquinone increases cytotoxicity of tetrahydroanthraquinones, whose cyclohexyl ring is substituted with two hydroxyl groups with the appropriate stereochemistry, and elimination of both or even a single hydroxyl, or change of stereochemistry of the tertiary hydroxyl eliminates biological activity, and additive hydroxyl moiety at C-1 of a tetrahydroanthraquinone might be the active profile for inhibiting lung tumor cell growth. Linker at a 3-atom with a phenyl or para-chlorophenyl moiety also can enhance cytotoxicity (Phunlap et al., 2013; Teiten et al., 2013; Li and Jiang, 2018). For anti-microbial activity, from the few studies, the hydroxyl group on the C-5 might be crucial to the antimicrobial activity (Yagi et al., 1993).

The most pharmacological researches of tetrahydroanthraquinones focused on cytotoxicity and antitumor mechanisms, suggesting its potential for developing antitumor drugs. While we found some of them are not suitable for drug research. Bitetrahydroanthraquinones are not suitable for drug research due to large weight and large steric resistance. Tetrahydro-5,8anthraquinones are a class of rare compounds with unstable structure, with tautomerism at the 9,10 positions of its 5,8-dione. They are not suitable for drug development due to the difficult in structural modification and pharmacological research. Hydroxyphenanthrenes is characteristic by the C9 carbonyl group undergoes a reduction reaction to form a hydroxy substitution. However, under acidic conditions, the C9 carbonyl group undergoes dehydration reaction, and becomes keto group. therefore, special attention needs to be paid to the conditions in pharmacological and synthetic research of Hydroxyphenanthrenes.

The tetrahydroanthraquinone isolated and identified are mainly from endophytes, and some of them are isolated from marine fungi and plants. Some pharmacological activities of tetrahydroanthraquinones are reported, yet are not enough. There is still a strong possibility that some tetrahydroanthraquinones with better regulatory activities remain in the shadow or have not been fully studied. Our study will serve as a valuable guideline for further research on the structural optimization, mechanism study, and development of tetrahydroanthraquinone as novel drugs.

\section{AUTHOR CONTRIBUTIONS}

SF: Manuscript writing and figure preparation; WW: Literature search and manuscript editing.

\section{FUNDING}

This research was funded by Natural science foundation of Guangdong Province (No.2016A030313034), Natural Science Foundation of Fujian Province (2018J01064), the Foundation of Third Institute of Oceanography SOA (2018021 and 2017001), COMRA program (DY135-B2-05 and DY135-B2-01). 


\section{REFERENCES}

Adhikari, A., and Mahar, K. S. (2016). DNA targeted anthraquinone derivatives: an important anticancer agents. Int. J. Pharm. Pharm. Sci. 8, 17-25.

Aly, A. H., Edrada-Ebel, R., Wray, V., Müller, W. E., Kozytska, S., Hentschel, U., et al. (2008). Bioactive metabolites from the endophytic fungus Ampelomyces sp. isolated from the medicinal plant Urospermum picroides. Phytochemistry 69, 1716-1725. doi: 10.1016/j.phytochem.2008.02.013

Becker, A. M., Rickards, R. W., Schmalzl, K. J., and Yick, H. C. (1978). Metabolites of Dactylaria lutea. J. Antibiotics 31, 324-329. doi: 10.7164/antibiotics.31.324

Bin, C., Duoji, P., Aiguo, X., Lan, L., Xun, Z., Yongchneg, L., et al. (2016) Tetrahydroanthraquinone derivatives from Alternaria sp. XZSBG -1. Acta Scientlarum Naturalium Universit. Sunyatesni 55, 91-95. doi: 10.13471/ j.cnki.acta.snus.2016.01.016

Chen, H., Zhong, L., Long, Y., Li, J., Wu, J., Liu, L., et al. (2012). Studies on the synthesis of derivatives of marine-derived bostrycin and their structure-activity relationship against tumor cells. Marine Drugs 10, 932-952. doi: 10.3390/ md10040932

Chen, C. H., Xiao, W. W., Jiang, X. B., Wang, J. W., Mao, Z. G., Lei, N., et al. (2013). A Novel Marine Drug, SZ-685C, Induces Apoptosis of MMQ Pituitary Tumor Cells by Downregulating miR-200c. Curr. Med. Chem. 20, 2145-2154. doi: 10.2174/0929867311320160007

Chen, B., Shen, Q., Zhu, X., and Lin, Y. (2014). The anthraquinone derivatives from the fungus Alternaria sp. XZSBG-1 from the saline lake in Bange, Tibet, China. Molecules 19, 16529-16542. doi: 10.3390/molecules191016529

Choomuenwai, V., Andrews, K. T., and Davis, R. A. (2012). Synthesis and antimalarial evaluation of a screening library based on a tetrahydroanthraquinone natural product scaffold. Bioorg. Med. Chem. 20, 7167-7174. doi: 10.1016/ j.bmc.2012.09.052

Cong, W., Juan, W., Yuhong, H., Hong, C., Yan, L., Lili, Z., et al. (2013). Antimycobacterial activity of marine fungus-derived 4-deoxybostrycin and nigrosporin. Molecules 18, 1728-1740. doi: 10.3390/molecules18021728

Debbab, A., Aly, A. H., Edrada-Ebel, R., Wray, V., M̈ller, W. E., Totzke, F., et al. (2009). Bioactive metabolites from the endophytic fungus Stemphylium globuliferum isolated from Mentha pulegium. J. Natural Products 72, 626631. doi: $10.1021 / \mathrm{np} 8004997$

Dongni, C., Hanxiang, L., Zhigang, S., and Yongjun, L. (2013).Bostrycin induces apoptosis of breast cancer cells by inhibiting the activity of PTP1B, in: The 8th National Academic Conference on Chemical Biology.

Elsworth, C., Gill, M., and Ten, A. (1999). Pigments of fungi. LXII.(1S, 3R)austrocortirubin: isolation from the fungus Dermocybe splendida and synthesis from (S)-citramalic acid. Aust. J. Chem. 52, 1115-1117. doi: $10.1071 / \mathrm{CH} 99141$

Feng, S. X., Hao, J., Chen, T., and Qiu, S. X. (2011). A new anthraquinone and two new tetrahydroanthraquinones from the roots of Prismatomeris connata. Helv. Chim. Acta 94, 1843-1849. doi: 10.1002/hlca.201100108

Feng, S., Zhang, M., Xu, J., Hu, Y., and Prisconnatanones, A. (2016). a cytotoxic naphthoquinone from Prismatomeris connata, suppresses the proliferation of human laryngocarcinoma HEp-2 cells in vitro. Natural Product Res. 30, $2840-$ 2844. doi: $10.1080 / 14786419.2016 .1160234$

Feng, S., Wang, Z., Zhang, M., Zhu, X., and Ren, Z. (2018). HG30, a tetrahydroanthraquinone compound isolated from the roots of Prismatomeris connate, induces apoptosis in human non-small cell lung cancer cells. Biomed. Pharmacother. 100, 124-131. doi: 10.1016/j.biopha.2018.02.005

Genov, M., Kreiseder, B., Nagl, M., Drucker, E., Wiederstein, M., Muellauer, B., et al. (2016). Tetrahydroanthraquinone derivative ( \pm )-4-deoxyaustrocortilutein induces cell cycle arrest and apoptosis in melanoma cells via upregulation of p21 and p53 and downregulation of NF-kappaB. J. Cancer 7, 555. doi: 10.7150/jca.13614

Höller, U., Gloer, J. B., and Wicklow, D. T. (2002). Biologically active polyketide metabolites from an undetermined fungicolous hyphomycete resembling Cladosporium. J. Natural Products 65, 876-882. doi: 10.1021/np020097y

Han, N.-N., Li, X., Tao, L., and Zhou, Q. (2018). Doxorubicin and rhein loaded nanomicelles attenuates multidrug resistance in human ovarian cancer. Biochem. Biophys. Res. Commun. 498, 178-185. doi: 10.1016/j.bbrc.2018.01.042

Huang, C., Jin, H., Song, B., Zhu, X., Zhao, H., Cai, J., et al. (2012). The cytotoxicity and anticancer mechanisms of alterporriol L, a marine bianthraquinone, against MCF-7 human breast cancer cells. Appl. Microbiol. Biotechnol. 93, 777-785. doi: 10.1007/s00253-011-3463-4
Huang, X., Sun, X., Lin, S.e., Xiao, Z. E., Li, H., Bo, D., et al. (2014). Xylanthraquinone, a new anthraquinone from the fungus Xylaria sp. 2508 from the South China Sea. Natural Product Res. 28, 111-114. doi: 10.1080/ 14786419.2013.850687

Kanamaru, S., Honma, M., Murakami, T., Tsushima, T., Kudo, S., Tanaka, K., et al. (2012). Absolute stereochemistry of altersolanol A and alterporriols. Chirality 24, 137-146. doi: 10.1002/chir.21035

Khamthong, N., Rukachaisirikul, V., Tadpetch, K., Kaewpet, M., Phongpaichit, S., Preedanon, S., et al. (2012). Tetrahydroanthraquinone and xanthone derivatives from the marine-derived fungus Trichoderma aureoviride PSUF95. Arch. Pharmacal. Res. 35, 461-468. doi: 10.1007/s12272-012-0309-2

Klaiklay, S., Rukachaisirikul, V., Phongpaichit, S., Pakawatchai, C., Saithong, S., Buatong, J., et al. (2012). Anthraquinone derivatives from the mangrovederived fungus Phomopsis sp. PSU-MA214. Phytochem. Lett. 5, 738-742. doi: 10.1016/j.phytol.2012.08.003

Li, Y., and Jiang, J. G. (2018). Health functions and structure-activity relationships of natural anthraquinones from plants. Food Funct. 9 (12), 6063-6080. doi: $10.1039 / \mathrm{C} 8 \mathrm{FO} 01569 \mathrm{D}$

Liu, Y., Marmann, A., Abdel-Aziz, M. S., Wang, C. Y., Müller, W. E., Lin, W. H., et al. (2015). Tetrahydroanthraquinone derivatives from the endophytic fungus Stemphylium globuliferum. Eur. J. Organic Chem. 2015, 2646-2653. doi: 10.1002/ejoc.201500079

Mishra, P., Verekar, S., Deshmukh, S., Joshi, K., Fiebig, H., and Kelter, G. (2015). Altersolanol A: a selective cytotoxic anthraquinone from a P homopsis sp. Lett. Appl. Microbiol. 60, 387-391. doi: 10.1111/lam.12384

Moussa, M., Ebrahim, W., El-Neketi, M., Mándi, A., Kurtán, T., Hartmann, R., et al. (2016). Tetrahydroanthraquinone derivatives from the mangrove-derived endophytic fungus Stemphylium globuliferum. Tetrahedron Lett. 57, 40744078. doi: 10.1016/j.tetlet.2016.07.091

Ng, T. B., Cheung, R. C. F., Wong, J. H., Bekhit, A. A., and Bekhit, A. E.-D. (2015) Antibacterial products of marine organisms. Appl. Microbiol. Biotechnol. 99, 4145-4173. doi: 10.1007/s00253-015-6553-x

Phunlap, P., Damrong, S., Nongluksna, S., Nattaya, N., Kiminori, M., and Khanitha, P. (2013). Antiangiogenetic effects of anthranoids from Alternaria sp., an endophytic fungus in a Thai medicinal plant Erythrina variegata. Phytomed. Int. J. Phytother Phytopharmacol. 20, 918-922. doi: 10.1016/j.phymed.2013.03.019

Stoessl, A. (1969a). Some metabolites of Alternaria solani. Can. J. Chem. 47, 767776. doi: 10.1139/v69-125

Stoessl, A. (1969b). Relative stereochemistry of altersolanol A. Can. J. Chem. 47, 777-784. doi: 10.1139/v69-126

Teiten, M.-H., Mack, F., Debbab, A., Aly, A. H., Dicato, M., Proksch, P., et al. (2013). Anticancer effect of altersolanol A, a metabolite produced by the endophytic fungus Stemphylium globuliferum, mediated by its pro-apoptotic and anti-invasive potential via the inhibition of NF- $\mathrm{\kappa B}$ activity. Bioorg. Med. Chem. 21, 3850-3858. doi: 10.1016/j.bmc.2013.04.024

Uzor, P. F., Ebrahim, W., Osadebe, P. O., Nwodo, J. N., Okoye, F. B., Müller, W. E. G., et al. (2015). Metabolites from Combretum dolichopetalum and its associated endophytic fungus Nigrospora oryzae - Evidence for a metabolic partnership. Fitoterapia 105, 147-150. doi: 10.1016/j.fitote.2015.06.018

Uzor, P. F., Osadebe, P. O., and Nwodo, N. J. (2017). Antidiabetic Activity of Extract and Compounds from an Endophytic Fungus Nigrospora oryzae. Drug Res. 67, 308-311. doi: 10.1055/s-0042-122777

Wang, D., Wang, S., Liu, Q., Wang, M., Wang, C., and Yang, H. (2013). SZ-685C exhibits potent anticancer activity in both radiosensitive and radioresistant NPC cells through the miR-205-PTEN-Akt pathway. Oncol. Rep. 29, 23412347. doi: 10.3892/or.2013.2376

Wang, C., Ding, X., Feng, S.-X., Guan, Q., Zhang, X.-P., Du, C., et al. (2015). Seven new tetrahydroanthraquinones from the root of Prismatomeris connata and their cytotoxicity against lung tumor cell growth. Molecules 20, 22565-22577. doi: $10.3390 /$ molecules 201219856

Wang, X., Tan, T., Mao, Z.-G., Lei, N., Wang, Z.-M., Hu, B., et al. (2015). The marine metabolite SZ-685C induces apoptosis in primary human nonfunctioning pituitary adenoma cells by inhibition of the Akt pathway in vitro. Marine Drugs 13, 1569-1580. doi: 10.3390/md13031569

Wang, Y., Islam, M. A., Davis, R. A., and Mcalpine, S. R. (2015). The fungal natural product (1S, 3S)-austrocortirubin induces DNA damage in HCT116 cells via a mechanism unique from other DNA damaging agents. Bioorg. Med. Chem. Lett. 25, 249-253. doi: 10.1016/j.bmcl.2014.11.055 
Wei-Sheng, C., Jun-Na, H., Yu-Biao, G., Hui-Ling, Y., Can-Mao, X., Yong-Cheng, L., et al. (2011). Bostrycin inhibits proliferation of human lung carcinoma A549 cells via downregulation of the PI3K/Akt pathway. J. Exp. Clin. Cancer Res. 30, 17. doi: 10.1186/1756-9966-30-17

Xie, G. E., Zhu, X., Li, Q., Gu, M., He, Z., Wu, J., et al. (2010). SZ-685C, a marine anthraquinone, is a potent inducer of apoptosis with anticancer activity by suppression of the Akt/FOXO pathway. Br. J. Pharmacol. 159, 689-697. doi: 10.1111/j.1476-5381.2009.00577.x

Xuekui, X., Qing, L., Jia, L., Changlun, S., Jianye, Z., Yonggang, Z., et al. (2011). Two new derivatives of griseofulvin from the mangrove endophytic fungus Nigrospora sp. (strain No. 1403) from Kandelia candel (L.) Druce. Planta Med. 77, 1735-1738. doi: 10.1055/s-0030-1271040

Yagi, A., Okamura, N., Haraguchi, H., Abot, T., and Hashimoto, K. (1993). Antimicrobial tetrahydroanthraquinones from a strain of Alternaria solani. Phytochemistry 33, 87-91. doi: 10.1016/0031-9422(93)85401-C

Zhang, N., Zhang, C., Xiao, X., Zhang, Q., and Huang, B. (2016). New cytotoxic compounds of endophytic fungus Alternaria sp. isolated from Broussonetia papyrifera (L.) Vent. Fitoterapia 110, 173-180. doi: 10.1016/j.fitote.2016.03.014

Zhang, S. L., Wu, Y. C., Cheng, F., Guo, Z. Y., and Chen, J. F. (2016). Anti-PRRSV effect and mechanism of tetrahydroaltersolanol C in vitro. J. Asian Natural
Products Res. 18, 303-314. doi: 10.1080/10286020.2015.1072516

Zhou, X.-M., Zheng, C.-J., Chen, G.-Y., Song, X.-P., Han, C.-R., Li, G.-N., et al. (2014). Bioactive anthraquinone derivatives from the mangrove-derived fungus Stemphylium sp. 33231. J. Natural Products 77, 2021-2028. doi: $10.1021 / \mathrm{np} 500340 \mathrm{y}$

Zhu, X., He, Z., Wu, J., Yuan, J., Wen, W., Hu, Y., et al. (2012). A marine anthraquinone SZ-685C overrides adriamycin-resistance in breast cancer cells through suppressing Akt signaling. Marine Drugs 10, 694-711. doi: 10.3390/ md10040694

Conflict of Interest: The authors declare that the research was conducted in the absence of any commercial or financial relationships that could be construed as a potential conflict of interest.

Copyright (C) 2020 Feng and Wang. This is an open-access article distributed under the terms of the Creative Commons Attribution License (CC BY). The use, distribution or reproduction in other forums is permitted, provided the original author(s) and the copyright owner(s) are credited and that the original publication in this journal is cited, in accordance with accepted academic practice. No use, distribution or reproduction is permitted which does not comply with these terms. 